\title{
PENINGKATAN KREATIVITAS MAHASISWA PADA PENGGUNAAN ALAT PRAKTIKUM SEDERHANA FISIKA DASAR 1 DI FKIP UNIVERSITAS MALIKUSSALEH
}

\author{
Nuraini Fatmi \\ Fakultas Keguruan dan Ilmu Pendidikan, Universitas Malikussaleh \\ e-mail: nurainifatmi@unimal.ac.id
}

\begin{abstract}
ABSTRAK : Tujuan penelitian adalah untuk mengetahui : Peningkatan kreativitas pada penggunaan alat praktikum fisika dasar 1, Respon mahasiswa saat penggunaan alat praktikum fisika dasar satu. Data penelitian diperoleh dari lembar observasi, tes soal uraian, angket dan dokumentasi, yakni menggunakan metode penelitian tindakan kelas. Teknik analisis data menggunakan statistic deskriptif dengan rumus persentase. Hasil penelitian didapatkan bahwa: Data hasil observasi kreativitas mahasiswa menunjukkan kreativitas mahasiswa pada siklus I mencapai kategori tingggi pada kemampuan berpikir lancar (fluency) 71,43\%, pada rasa ingin tahu $71,43 \%$. Sedangkan pada siklus II meningkat pada katagori tinggi adalah kemampuan berpikir lancar(fluency) $81,25 \%$, rasa ingin tahu $81,25 \%$, berani mengambil resiko $87,50 \%$. Hasil tes kreativitas mahasiswa mengalami peningkatan melalui perolehan rata- rata 56,45 di siklus I mengalami peningkatan 8,33 kemudian 63,96 di siklus II mengalami peningkatan 10,63. Data hasil angket respon mahasiswa menunjukkan respon mahasiswa pada siklus I mencapai kategori baik dengan persentase tertinggi 93,42\%.
\end{abstract}

\section{Kata kunci : Kreativitas, alat praktikum}

\section{IMPROVING CREATIVITY OF STUDENTS IN USE SIMPLE PRACTICUM EQUIPMENT OF BASIC PHYSICS 1 IN FKIP MALIKUSSALEH UNIVERSITY}

ABSTRACT: The purpose of the study was to find out: Increased creativity in the use of basic physics practicum tools 1 , student responses when using a basic physics practicum tool one. The research data was obtained from observation sheets, test questions, questionnaires and documentation, namely using classroom action research methods. Data analysis techniques used descriptive statistics with percentage formulas. The results showed that: Data from observations of student creativity showed the creativity of students in the first cycle reached the high category in the ability to think fluently $71.43 \%$, in curiosity $71.43 \%$. Whereas in the second cycle increased in the high category is the ability to think fluently $81.25 \%$, curiosity $81.25 \%$, dare to risk $87.50 \%$. The creativity test results of students experienced an increase through an average acquisition of 56.45 in the first cycle experiencing an increase of 8.33 then 63.96 in the second cycle increased by 10.63. Data from the student response questionnaire showed that the response of students in the first cycle reached a good category with the highest percentage of $93.42 \%$.

\section{Keywords: Creativity, practicum tool}

\section{PENDAHULUAN}

Pendidikan sangat penting dalam penentu kemajuan suatu negara dan kesejahteraan rakyat. Tidak ada suatu negara maju memiliki mutu pendidikan yang rendah. Seperti halnya Jepang dan Amerika Serikat adalah negara yang mempusatkan sistem politiknya dalam bidang pendidikan yaitu dengan cara menekankan pendidikan sebagai prioritas utama dalam 
pembangunan negaranya. Perbaikan mutu pendidikan di Indonesia dapat dilakukan dengan perbaikan sistem belajar dan pembelajaranya. Dalam buku psikologi pendidikan menjelaskan bahwa inti kegiatan pendidikan adalah proses belajar dan pembelajaran. Belajar dapat berlangsung secara internal terhadap semua pengalaman belajar dan dapat berlangsung melalui pengalaman yang dirancang guru (Sanjaya.2008). Pembelajaran disekolah dan perguruan tinggi dewasa ini, tidak sesuai dengan yang diharapkan apabila dikaitkan dengan kreativitas siswa/mahasiswa terhadap materi pelajaran.

Selama ini pembelajaran fisika masih berorientasi pada telling science, belum bergeser ke orientasi doing science. Hal ini mengakibatkan kurang kreatifitas dosen dan mahasiswa selama proses pembelajaran berlangsung, sehingga sering ditemukan pembelajaran yang berpusat pada dosen. Situasi pembelajaran seperti ini mengakibatkan pembelajaran fisika cenderung hanya menekankan pada aspek produk seperti menghapal konsep-konsep dan rumus, tidak memberikan kesempatan siswa terlibat aktif dalam proses pembelajaran fisika.

Sugihartono (2007) menyatakan bahwa pembelajaran merupakan suatu upaya yang dilakukan dengan sengaja oleh pendidik untuk menyampaikan ilmu pengetahuan, mengorganisasi dan menciptakan sistem lingkungan dengan berbagai metode sehingga siswa dapat melakukan kegiatan belajar yang efektif dan efisien. Menurut Erman Suherman (2003), dalam arti sempit pembelajaran adalah proses sosialisasi individu siswa dengan lingkungan sekolah seperti guru, sumber/fasilitas, dan teman sesama siswa. Menurut Zainal Muttaqien (2016), pembelajaran adalah proses, perbuatan, cara mengajar atau mengajarkan sehingga anak didik mau belajar. Pembelajaran adalah proses interaksi siswa dengan pendidik dan sumber belajar pada suatu lingkungan belajar (Wikipedia).

Sejalan dari beberapa pengertian di atas, maka dapat disimpulkan bahwa pembelajaran adalah proses sosialisasi dan interaksi individu siswa dengan lingkugan sekolah seperti guru, sumber belajar, dan teman sesama siswa sehingga siswa mau belajar. Temuan masalah ini juga serupa dengan yang terjadi di universitas.

Berdasarkan hasil observasi awal yang penulis lakukan di temukan bahwa selama ini pembelajaran fisika dasar 1 di kelas dinilai masih telling science belum bergeser ke orientasi doing scienc, dan. mahasiswa hanya mampu menyelesaikan soal-soal dengan cara penyelesaian yang diajarkan oleh dosen dan kurang mampu untuk mencari alternatif penyelesaian lainnya serta mahasiswa kurang berani mengajukan pertanyaan. Hal ini dikarenakan tidak adanya alat praktikum fisika dasar 1, sehingga proses pembelajaran hanya bisa dilakukan dengan menceritakan konsep dan bentuk alat serta pemakaiannya, hal ini mengakibatkan mahasiswa kebanyakan menghayal saat proses pembelajaran.

Hasil pengamatan penulis menyatakan bahwa di fakultas keguruan dan ilmu pengetahuan khusus nya prodi pendidikan fisika belum tersedianya alat yang lengkap dilaboratorium, hal ini lah yang menjadi dasar pembelajaran yang berlangsung masih telling science. maka solusi tepat yang ditawarkan penulis adalah membuat alat praktikum sederhana fisika dasar 1, kenapa sederhana karena kegiatan pembuatan ini tidak dibiayai oleh pemerintah, kegiatan ini hanya inisiatif untuk memudahkan mahasiswa dalam memahami konsep fisika dasar I sehingga penghayalan selama proses pembelajaran dapat dihilangkan.

Berdasarkan latar belakang sebagaimana diuraikan di atas maka dianggap perlu melakukan penelitian yang berjudul" Peningkatan kreativitas mahasiswa pada penggunaan alat praktikum sederhana fisika dasar 1 di fkip universitas malikussaleh"

\section{METODE}


Penelitian ini dilaksanakan di prodi pendidikan fisika, fakultas keguruan dan ilmu pengetahuan, Jalan Cot Tengku Nie Reuleut, kecematan Muara Batu Kabupaten Aceh Utara. Penelitian ini dilaksanakan pada tahun 2016 di semester ganjil. Adapun yang menjadi populasi pada penelitian ini adalah seluruh mahasiswa prodi pendidikan fisika disetiap angkatan. Namun yang menjadi sampel pada penelitian hanya pada kelas A2 yang mempunyai kreativitas yang berbeda-beda. Penelitian ini merupakan penelitian PTK, Untuk mendapatkan hasil penelitian yang valid maka sebelum melaksanakan penelitian terlebih dahulu dibuat rancangan penelitiannya, namun secara garis besar terdapat empat tahapan yang lazim dilalui, yaitu (a) perencanaan, (b) pelaksanaan, (c) pengamatan, (d) refleksi ( Suharsimi, 2010).

Gambaran dari tahap-tahap penelitian digambar dalam siklus sebagai berikut:

Teknik Pengumpulan Data

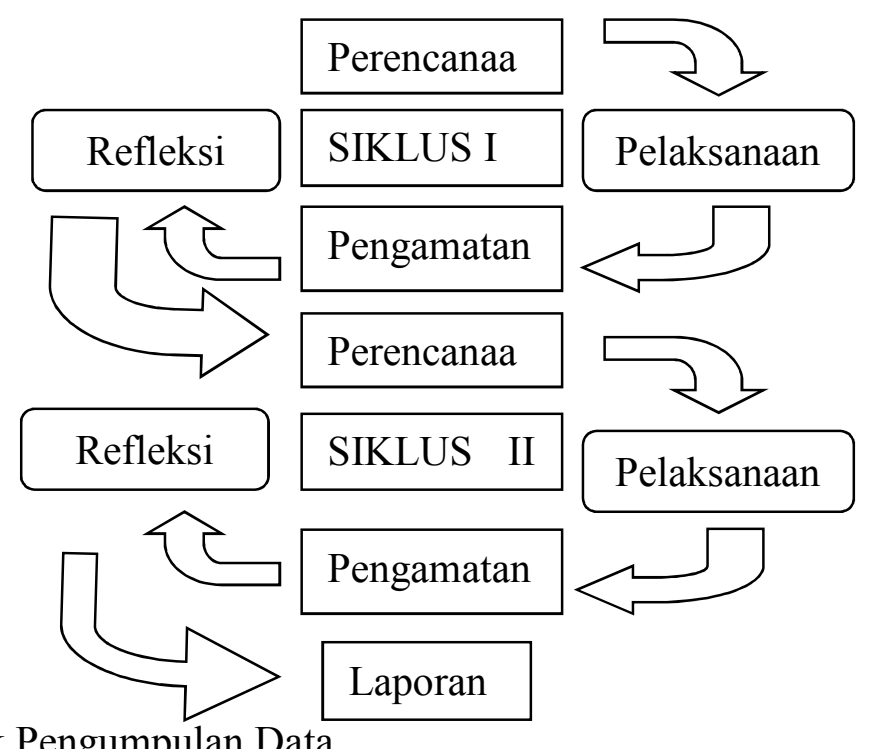

\section{Observasi}

Data yang dikumpulkan melalui teknik observasi ini berdasarkan pada pedoman observasi yang telah disusun. Ada dua pedoman observasi yang akan digunakan yaitu pedoman observasi kreativitas mahasiswa dan pedoman observasi kegiatan pembelajaran saat menggunakan alat praktikum.

2. Tes

Tes digunakan untuk mengetahui perkembangan kreativitas mahasiswa setelah dilakukan pembelajaran serta untuk mengetahui respons siswa terhadap pembelajaran. Respon mahasiswa dapat dilihat dari hasil jawaban tes mahasiswa. Soal yang diberikan dalam tes ini adalah soal uraian. Tes dilakukan pada setiap akhir siklus.

\section{Angket}

Angket yang akan diberikan kepada mahasiswa terdiri dari dua buah angket. Angket kreativitas siswa digunakan untuk mengetahui aktivitas yang dilakukan siswa ketika proses pembelajaran berlangsung dan angket respons siswa digunakan untuk mengetahui tanggapan siswa terhadap pembelajaran yang sudah dilaksanakan. Kedua buah angket tersebut diberikan kepada seluruh mahasiswa pada akhir siklus pembelajaran.

\section{Dokumentasi}


Dokumentasi digunakan untuk memperkuat data yang diperoleh dalam observasi. Untuk memberikan gambaran secara konkret mengenai kegiatan pembelajaran digunakan dokumentasi foto.

\section{HASIL DAN PEMBAHASAN}

\section{Hasil}

Tabel 4.3. Daftar Nilai Tes Kreativitas Mahasiswa Pada Siklus-I dan Siklus-II Pada Penggunaan Alat Praktikum.

\begin{tabular}{|c|c|c|c|c|c|}
\hline \multirow{2}{*}{ No } & \multirow{2}{*}{$\begin{array}{c}\text { Mahasi } \\
\text { swa }\end{array}$} & \multirow[b]{2}{*}{ Siklus I } & \multirow[b]{2}{*}{ Meningkat } & \multirow[b]{2}{*}{ Siklus II } & \multirow[b]{2}{*}{ Meningkat } \\
\hline & & & & & \\
\hline 1 & 2 & 3 & 4 & 5 & 6 \\
\hline 1 & $\mathrm{X}-1$ & 65 & 5 & 70 & 5 \\
\hline 2 & $X-2$ & 60 & 5 & 65 & 5 \\
\hline 3 & $X-3$ & 50 & 10 & 60 & 5 \\
\hline 4 & $X-4$ & 50 & 10 & 60 & 5 \\
\hline 5 & $X-5$ & 40 & 10 & 50 & 25 \\
\hline 6 & $X-6$ & 40 & 20 & 60 & 5 \\
\hline 7 & $X-7$ & 70 & - & 70 & 10 \\
\hline 8 & $X-8$ & 50 & 5 & 55 & 5 \\
\hline 9 & $X-9$ & 65 & 20 & 80 & 10 \\
\hline 10 & $X-10$ & 55 & 5 & 60 & 25 \\
\hline 11 & $X-11$ & 60 & 5 & 65 & 5 \\
\hline 12 & $X-12$ & 45 & 25 & 70 & 5 \\
\hline 13 & $X-13$ & 55 & 5 & 60 & 25 \\
\hline 14 & $X-14$ & 55 & 5 & 60 & 10 \\
\hline 15 & $X-15$ & 60 & 10 & 70 & 5 \\
\hline 16 & $X-16$ & 55 & 5 & 60 & 5 \\
\hline 17 & $X-17$ & 50 & 15 & 65 & 10 \\
\hline 18 & $X-18$ & 60 & 5 & 65 & 5 \\
\hline 19 & $X-19$ & 60 & 5 & 65 & 20 \\
\hline 20 & $X-20$ & 55 & 5 & 60 & 25 \\
\hline 21 & $X-21$ & 65 & 5 & 70 & 10 \\
\hline 22 & $X-22$ & 60 & - & 55 & 10 \\
\hline 23 & $X-23$ & 65 & 5 & 70 & 5 \\
\hline 24 & $X-24$ & 60 & 15 & 75 & 15 \\
\hline \multicolumn{2}{|c|}{ Jumlah } & 1355 & 200 & 1535 & 255 \\
\hline \multicolumn{2}{|c|}{ Rata-rata } & 56,45 & 8,33 & 63,96 & 10,63 \\
\hline
\end{tabular}

Tabel 4.4. Distribusi Frekuensi Peningkatan Kreativitas Mahasiswa

\begin{tabular}{llcccc}
\hline Interval & Kriteria & $\begin{array}{c}\text { Siklus } \\
\text { I }\end{array}$ & Meningkat & $\begin{array}{c}\text { Siklus } \\
\text { II }\end{array}$ & Meningkat \\
\hline
\end{tabular}




\begin{tabular}{|c|c|c|c|c|c|}
\hline & & $(f)$ & & $(f)$ & \\
\hline 1 & 2 & 3 & 4 & 5 & 6 \\
\hline $80-100$ & $\begin{array}{c}\text { Baik } \\
\text { Sekali }\end{array}$ & 0 & 1 & 1 & 7 \\
\hline $66-79$ & Baik & 1 & 6 & 7 & 3 \\
\hline $56-65$ & Cukup & 11 & 2 & 13 & - \\
\hline $40-55$ & Kurang & 10 & - & 3 & - \\
\hline $30-39$ & Gagal & 0 & - & - & - \\
\hline
\end{tabular}

Peneliti juga menyebarkan angket kepada seluruh mahasiswa kelas A2 Prodi pendidikan fisika, untuk mengetahui respon mahasiswa terhadap penggunaan alat praktikum. Penyebaran angket tersebut dilakukan setiap akhir siklus I dan II.

Tabel 4.5. Hasil angket respon mahasiswa pada siklus I

\begin{tabular}{|c|c|c|}
\hline \multirow{2}{*}{ Aspek yang Diamati } & Persen & \multirow[t]{2}{*}{ Kualifika } \\
\hline & tase & \\
\hline \multirow{2}{*}{$\begin{array}{l}\text { Mengembangkan kemampuan bertanya, } \\
\text { berkomunikasi, dan menyimpulkan bahasan. }\end{array}$} & 65,79 & Cukup \\
\hline & $\%$ & Baik \\
\hline \multirow{2}{*}{$\begin{array}{l}\text { Mengembangkan kemampuan berpikir sendiri } \\
\text { dalam memecahkan masalah }\end{array}$} & 93,42 & \multirow{2}{*}{ Baik } \\
\hline & $\%$ & \\
\hline \multirow[b]{2}{*}{ Kemampuan mahasiswa memberikan pendapat } & 64,47 & Cukup \\
\hline & $\%$ & Baik \\
\hline Kemampuan menemukan sendiri pola-pola atau & 77,63 & \multirow{2}{*}{ Baik } \\
\hline struktur-struktur melalui serangkaian pengalaman & $\%$ & \\
\hline mahasiswa belajar mandiri & $71,05 \%$ & Baik \\
\hline \multirow[b]{2}{*}{ Pemahaman terhadap bahan pelajaran } & 81,58 & \multirow{2}{*}{ Baik } \\
\hline & $\%$ & \\
\hline \multirow[b]{2}{*}{ Minat belajar mahasiswa } & 72,37 & \multirow[b]{2}{*}{ Baik } \\
\hline & $\%$ & \\
\hline
\end{tabular}

Tabel 4.6. Hasil angket respon mahasiswa pada siklus II

\begin{tabular}{|c|c|c|c|c|}
\hline \multirow{2}{*}{\multicolumn{2}{|c|}{ Aspek yang Diamati }} & & Persent & Kualifi \\
\hline & & & ase & kasi \\
\hline Mengembangkan & kemampuan & bertanya, & $77,63 \%$ & Baik \\
\hline
\end{tabular}




\begin{tabular}{lcc}
\hline \multicolumn{3}{l}{ berkomunikasi, dan menyimpulkan bahasan. } \\
$\begin{array}{l}\text { Mengembangkan kemampuan berpikir sendiri } \\
\text { dalam memecahkan masalah }\end{array}$ & $88,16 \%$ & Baik \\
\hline $\begin{array}{l}\text { Kemampuan mahasiswa memberikan pendapat } \\
\text { Kemampuan menemukan sendiri pola-pola atau } \\
\text { struktur-struktur melalui serangkaian pengalaman }\end{array}$ & $88,16 \%$ & Baik \\
\hline mahasiswa belajar mandiri & $84,21 \%$ & Baik \\
\hline Pemahaman terhadap bahan pelajaran & $75 \%$ & Baik \\
\hline Minat belajar mahasiswa & $80,26 \%$ & Baik \\
\hline
\end{tabular}

\section{Pembahasan}

Hasil penelitian diperoleh dalam tiga siklus pembelajaran yang dilakukan pada proses belajar mengajar di kelas A2 dengan rincian waktu 1 SKS. Pertemuan 1 dan 2 alokasi waktu 1 x 50 menit, pertemuan 3 alokasi waktu 1 x 50 menit. Pada penelitian ini, diamati oleh dua orang pengamat yaitu Ibu Syarifah Rita zahara, M.Pd, dosen bidang studi pendidikan fisika dan Safriana, M.Pd. Ketua Prodi Pendidikan Fisika di Fkip Unimal yang membantu penulis dalam mengamati mahasiswa selama proses praktikum berlangsung, sedangkan yang bertindak sebagai dosen pada saat penelitian adalah penulis sendiri. Tahap-tahap tersebut diuraikan sebagai berikut :

\section{Perencanaan}

Perencanaan merupakan tindakan yang dilakukan oleh peneliti, pada tahap awal mempersiapkan segala keperluan dalam melakukan penelitian, yaitu perangkat instrumen berupa Satuan Acara Perkuliahan (SAP) untuk siklus I, II dan III, modul praktikum, lembar observasi mahasiswa untuk setiap pertemuan, lembar respon siswa dan soal tes peningkatan kreativitas mahasiswa saat proses praktikum berlangsung. Peneliti juga melakukan pendekatan dan memotivasi siswa dalam menjawab pertanyaan sehingga keaktifan siswa dalam belajar maksimal.

\section{Pelaksanaan}

Pelaksanaan (tindakan) dilakukan setelah perencanaan dipersiapkan, siklus I berlangsung pada minggu pertama semester ganjil di matakuliah praktikum pada mahasiswa 2016. Pada kegiatan awal siklus I yang dilakukan adalah dosen mengarahkan penggunaan alat praktikum sesuai sap. Selanjutnya pada kegiatan praktikum mahasiswa dibagi dalam 8 kelompok dan setiap kelompok terdiri dari 5 atau 6 orang. Setelah siswa dibentuk dalam kelompok kecil seperti yang telah diatur sebelumnya, kemudian dosen menjelaskan secara umum tentang materi praktikum yang disesuaikan dengan indikator kreativitas, diakhir 
pelajaran peneliti mengevaluasi mahasiswa dengan membagikan soal tes kreativitas tahap I, pada siklus I belum semua siswa mengalami peningkatan kreativitas, oleh karena itu peneliti harus melakukan siklus II untuk memperbaiki kekurangan pada siklus I.

Siklus II dilakukan pada minggu 8 semester ganjil di matakuliah praktikum pada mahasiswa 2016, Pada kegiatan awal yang dilakukan adalah dosen mengarahkan penggunaan alat praktikum sesuai sap. Selanjutnya dosen melanjutkan menjelaskan mengenai materi praktikum yang disesuaikan dengan indikator kreativitas, diakhir pelajaran peneliti mengevaluasi mahasiswa dengan membagikan soal tes kreativitas tahap II, pada siklus II sudah mengalami peningkatan maka siklus III dianggap tidak perlu dilakukan lagi.

\section{Observasi}

Lembar pengamatan yang telah diisi oleh pengamat selama proses praktikum berlangsung, penulis memperoleh data tentang aktivitas mahasiswa. Aktivitas kegiatan penelitian peningkatan kreativitas pada penggunaan alat praktikum sederhana. Pada siklus I dan II yaitu hasil pengamatan terhadap aktivitas mahasiswa dinyatakan dengan persentase, Adapun secara ringkas data aktifitas mahasiswa selama praktikum berlangsung dapat dilihat pada tabel dibawah ini:

Tabel 4.1. Hasil observasi aktivitas mahasiswa pada siklus I

\begin{tabular}{lcc}
\multicolumn{1}{c}{ Aspek yang Diamati } & Persentase & Kualifika \\
& & si \\
\hline Kemampuan berpikir lancar (fluency) & $71,43 \%$ & Tinggi \\
\hline Kemampuan berpikir luwes(fleksibilitas) & $60,71 \%$ & Sedang \\
\hline $\begin{array}{l}\text { Kemampuan berpikir } \\
\text { (orisinalitas) }\end{array}$ & $57,14 \%$ & Sedang \\
\hline Kemampuan memperinci (elaborasi) & $50 \%$ & Sedang \\
\hline Kemampuan menilai (evaluasi) & $60,71 \%$ & Sedang \\
\hline Rasa ingin tahu & $71,43 \%$ & Tinggi \\
\hline Bersifat imajinatif & $35,71 \%$ & Sedang \\
\hline Merasa tertantang oleh kemajemukan & $60,71 \%$ & Sedang \\
\hline Berani mengambil resiko & $64,29 \%$ & Sedang \\
\hline Menghargai & $67,86 \%$ & Tinggi \\
\hline
\end{tabular}

Tabel 4.2. Hasil observasi aktivitas mahasiswa pada siklus II 


\begin{tabular}{lcc}
\multicolumn{1}{c}{ Aspek yang Diamati } & $\begin{array}{c}\text { Persentas } \\
\text { e }\end{array}$ & $\begin{array}{l}\text { Kualifi } \\
\text { kasi }\end{array}$ \\
\hline Kemampuan berpikir lancar (fluency) & $81,25 \%$ & Tinggi \\
\hline Kemampuan berpikir luwes(fleksibilitas) & $65,63 \%$ & Sedang \\
\hline Kemampuan berpikir orisinal (orisinalitas) & $56,25 \%$ & Sedang \\
\hline Kemampuan memperinci (elaborasi) & $65,63 \%$ & Sedang \\
\hline Kemampuan menilai (evaluasi) & $75 \%$ & Tinggi \\
\hline Rasa ingin tahu & $81,25 \%$ & Tinggi \\
\hline Bersifat imajinatif & $53,13 \%$ & Sedang \\
\hline Merasa tertantang oleh kemajemukan & $71,88 \%$ & Tinggi \\
\hline Berani mengambil resiko & $87,50 \%$ & Tinggi \\
\hline Menghargai & $71,88 \%$ & Tinggi \\
\hline
\end{tabular}

\section{Refleksi}

Refleksi merupakan kegiatan untuk mengingat kembali pembelajaran pada tiap-tiap siklus yang telah dipelajari, untuk menyempurnakan pada siklus berikutnya. Maka untuk memperoleh peningkatan kreativitas mahasiswa tidaklah mudah di dapat begitu saja, tetapi memerlukan perbaikan-perbaikan secara bertahap. Perbaikan dilakukan oleh peneliti pada tiap-tiap siklus. Pada siklus I keberhasilan yang diperoleh belum mengalami peningkatan kreativitas, karena pada siklus ini mahasiswa masih bingung pada penggunaan alat praktikum, hal ini dilihat dari kreativitas mahasiswa dalam mengerjakan soal tes tahap I, sehingga penelitian dilanjutkan lagi pada siklus ke dua.

Pada siklus II keberhasilan yang diperoleh dari data aktivitas guru dan siswa, respon, serta hasil tes mahasiswa sudah mengalami peningkatan dibandingkan siklus I, maka dalam hal ini tidak perlu pengadaan siklus III.

\section{KESIMPULAN}

Peningkatan kreativitas mahasiswa pada penggunaan alat praktikum fisika dasar 1 mengalami peningkatan serta mencapai kategori tinggi dengan data sebagai berikut:

a. Data hasil observasi kreativitas mahasiswa menunjukkan kreativitas mahasiswa pada siklus I mencapai kategori tingggi pada kemampuan berpikir lancar (fluency) $71,43 \%$, pada rasa ingin tahu $71,43 \%$ dan menghargai $67,86 \%$. Sedangkan pada siklus II meningkat pada katagori tinggi adalah kemampuan berpikir lancar(fluency) $81,25 \%$, kemampuan menilai (evaluasi) $75,00 \%$, rasa ingin tahu $81,25 \%$, merasa tertantang oelh kemajemukan $71,88 \%$, berani mengambil resiko $87,50 \%$ dan menghargai $71,88 \%$. 
b. Hasil tes kreativitas mahasiswa mengalami peningkatan melalui perolehan rata- rata 56,45 di siklus I mengalami peningkatan 8,33 kemudian 63,96 di siklus II mengalami peningkatan 10,63 .

c. Data hasil angket respon mahasiswa menunjukkan respon mahasiswa pada siklus I mencapai kategori baik dengan persentase tertinggi $93,42 \%$ pada indikator mengembangkan kemampuan berpikir sendiri dalam memecahkan masalah dan terdapat 2 indikator yang masih berada pada katagori cukup baik, sedangkan pada siklus II mengalami peningkatan pada semua indikator angket meningkat pada katagori baik.

\section{UCAPAN TERIMA KASIH}

Terima kasih kepada pihak yang sudah turut membantu terlaksananya penelitian ini, terima kasih yang terutama kepada asisten laboratorium pendidikan fisika yang telah membantu terlaksananya penelitian ini.

\section{DAFTAR PUSTAKA}

Abdul Majid. (2007). Perencanaan Pembelajaran. Bandung: PT. Remaja Rosdakarya.

Conny Semiawan, dkk . (1987). Memupuk Bakat dan Kreativitas Siswa Sekolah Menengah. Jakarta: PT. Gramedia.

Erman Suherman. (2003). Strategi Pembelajaran Matematika Kontemporer. Bandung: Jurusan Pendidikan Matematikan, Fakultas Pendidikan Matematika dan Ilmu Pengetahuan Alam, Universita Pendidikan Indonesia.

Hamzah B. Uno. (2007). Model Pembelajaran Menciptakan Proses Belajar Mengajar yang Kreatif dan Efektif. Jakarta: Bumi Aksara.

Sugihartono, dkk. (2007). Psikologi Pendidikan. Yogyakarta: UNY Press.

Suharsimi Arikunto dkk. (2010). PenelitianTindakanKelas. Jakarta: BumiAksara.

Wina Sanjaya. (2008). Strategi Pembelajaran Berorientasi Standar Proses Pendidikan. Jakarta: KencanaPrenada Media Group.

Wikipedia. (2008). Pembelajaran. http://id.wikipedia.org/wiki/Pembelajaran - 19k. Diakses tanggal 10 Juli 2016.

Zainal Mutaqqien. (2016). Pengertian dan Hakekat Pembelajaran. http://elmuttaqie.wordpress.com/2016/07/18/pengertian-dan-hakekat-pembelajaran/ 13k. Diakses tanggal 18 Juli 2016. 